\title{
The Role of Intellectual Capital Management in Enhancing Organization' Competitiveness: An Empirical Study on Algerian Insurance Organizations
}

\author{
Dr. Zoubeir Ayache \\ Research Professor, University Alarbi Ben Mehidi Oum El Baouaghi, Algeria \\ zoubeirayache@yahoo.fr \\ Dallel Adjali \\ Research Professor, University Alarbi Ben Mehidi Oum El Baouaghi, Algeria \\ Adjali_d@yahoo.fr
}

Doi:10.5901/mjss.2015.v6n3p311

Abstract

The aim of this study is to empirically examine the three stages of intellectual capital management (knowledge management stage, innovation management stage and intellectual property management stage) and their relationship with business competitiveness in the Algerian insurance organizations. This study was conducted based on a psychometrically validated questionnaire designed and distributed to a random sample of 551 managers in 23 Algerian insurance organizations. The response rate was $26 \%$ as 209 managers filled the questionnaire in 16 insurance organizations. We used statistical methods to analyze the four principal hypotheses developed. In particularly, we found that: (a) Intellectual capital Management (ICM) has an important existence in Algerian Insurance organizations. (b) competitiveness have an important existence in Algerian Insurance organizations. (C) Intellectual property management(IPM) is positively associated with competitiveness in Algerian Insurance organizations. (d) There is a statistically significant difference amongst Algerian insurance organizations due to privacy determinants (type, experience and turnover).

Keywords: Intellectual capital management, knowledge management stage, innovation management stage, intellectual property management stage, competitiveness.

\section{Introduction}

Several factors inherent in the current global situation have emphasized the importance on intellectual capital. These Contemporary forces-such as globalization, new technology, relatively free capital, increased competition, changes in customer demands, the demand for innovation, changes in economic and political structures and the role of the state in supporting knowledge economies- are constantly reshaping the way business is carried out(Guthrie and Petty,1999; Buckley and Carter2000; Thorne and Smith2000; Volberda et al 2001). Previous research has claimed that firms have begun to realize that technology-based competitiveness is transient and that sustainable advantage lies in managing intellectual capital, that is, intangible resources(Johansan et al, 1999), and in a firm's ability to create value through managing knowledge(Lev 2001; Sveiby 2001).

The term intellectual capital has existed for a long time but the concept is not in common use yet throughout the business world. Intellectual capital (IC) can be defined as all nonmonetary and nonphysical resources that are fully or partly controlled by the organization and that contribute to the organization's value creation.

Intellectual capital has been defined in several different ways. It has been defined from Larry Prusad of Ernst\& Young as: Intellectual material that has been formalized, capture and leveraged to produce a higher-valued asset(Stewart, 2004), the knowledge that can be converted into value(Indra abeysekera, 2008). We all know, at least implicitly, what knowledge is. Many will think of "scientific knowledge" or even "information technology" and their outputs such as pharmaceuticals or software. Operationally, and for its strategic deployments, intellectual capital can be thought of as falling within the following specific categories:

- The Brand, being a significance and identity conveying the values and meanings of an enterprise, its products and services, and ultimately its role with the customer, consumer, and society.

- Intellectual Property, including trademarks, copyrights, patents, trade secrets, licenses, and intellectual property strategies. 
- Corporate Intellect, the intelligence, energy, and creativity of the organization, including knowledge, know how, trade secrets, information, and data.

- Corporate Culture, the organization's way of doing business, its rituals, its practices, its history, "corporate memory" and its social and cultural capital.

- Human Capital, the people, with their education, ethical character, abilities, talents, and relationships.

- Innovation, the work product of knowledge workers, and the ability to invent and take products and services to market.

- Goodwill, the residual intangible, intellectual value in an enterprise that hasn't found its proper classification as either a tangible or specific intangible asset.

While each of these categories enjoys high levels of strategic significance in the modern enterprise, the primary intellectual capital drivers, across all companies that can be immediately accessed and managed strategically, are the brand and intellectual property(Lindsay Moore and Lesley Craig, 2008). Although there are many different ways of subdividing IC, the one favored by the authors is to divide intellectual capital into three categories based on their economic behavior. These are:

- Relational: These include all relationships that the organization has, such as customers, consumers, intermediaries, representatives, suppliers, partners, owners, lenders, and the like;

- Organizational: The intuitive definition was best articulated by Leif Edvinsson as "all those things that remain in the organization when the employees have left the building but that you cannot find in the balance sheet." This includes resources such as brands, intellectual property, processes, systems, organizational structures, information (on paper or in data bases), and the like(Goran, R.\& others ,2005);

- Human: All the attributes that relate to individuals as resources for the company and under the requirement that these attributes cannot be replaced by machines or written down on a piece of paper. This includes resources such as competence, attitude, skill, tacit knowledge, personal networks, and the like(Goran, R.\& others ,2005).

These IC resources all form the basis for potential competitive advantage but few of them make it into any disclosure document in a verifiable form(Goran, R.\& others ,2005).

\section{Intellectual Capital Management Model}

To develop intellectual capital management model for organizations, it is important to illustrate the business cycle of IC and to link it to the functions of organization management. These include:

- Function of managing resources of the organization;

- Function of managing process of production;

- $\quad$ And the function of maximize value of the organization (value of stakeholders).

These functions or stages are the principal basis of organizations management. Now in economy of knowledge where 80 percent of organization value is made of intangible assets, ICM must be inheriting at each of these stages. The studies found that business cycle of IC follows the same stages as those stages above. Under this business cycle, intellectual capital develops from being a resource with a potential value to an asset with a perceived value, to becoming a product with a market value(Nermien Al-Ali, 2003, p61).

To incorporate the intellectual capital business cycle and stages into organizations management, this model of ICM adopts a functional classification of intellectual capital as the underlying IC model.

- Resource management offset by knowledge resources;

- Managing process of production offset by innovation resources and processes;

- Maximize value offset by intellectual property.

These groups are then managed, each according to its stage of development under three stages as follows. As illustrated in (Table 1), each stage is mostly focused on managing one particular form of intellectual capital(Nermien AlAli, 2003, p63). 
Table (1): The Stages of IC under the ICM Model

\begin{tabular}{|c|c|c|c|c|}
\hline $\begin{array}{c}\text { Intellectual Capital/ } \\
\text { Stage of development }\end{array}$ & Human Capital & Customer Capital & Structural Capital & Purpose \\
\hline $\begin{array}{c}\text { Knowledge management } \\
\text { stage }\end{array}$ & $\begin{array}{c}\text { Tacit knowledge, } \\
\text { experience, brainpower, } \\
\text { vision }\end{array}$ & $\begin{array}{c}\text { Experience, knowledge, } \\
\text { relations, networks }\end{array}$ & IT databases, & Value creation \\
\hline $\begin{array}{c}\text { Innovation management } \\
\text { stage }\end{array}$ & $\begin{array}{c}\text { Ideas, product, concepts, } \\
\text { skills. }\end{array}$ & $\begin{array}{c}\text { Ideas, product, concepts, } \\
\text { feedbacks, relationships }\end{array}$ & $\begin{array}{c}\text { Work systems, business } \\
\text { processes. }\end{array}$ & Value extraction \\
\hline $\begin{array}{c}\text { Intellectual property } \\
\text { management stage }\end{array}$ & Know-how, know-why. & $\begin{array}{c}\text { Brand identity, reputation, } \\
\text { strategic alliances. }\end{array}$ & $\begin{array}{c}\text { Patents, trademarks, } \\
\text { copyrights, trade secrets. }\end{array}$ & $\begin{array}{c}\text { Value } \\
\text { maximization }\end{array}$ \\
\hline
\end{tabular}

Source: Nermien Al-Ali, 2003, p64.2.1. The First Stage: Managing IC as Raw Knowledge Resources

At this stage, IC-whether human, customer, or structural capital-is still in its raw form. Managing IC at this stage of its business cycle is the management of the organization's knowledge resources in every form they come in, hence the stage of knowledge management. This stage is mostly focused on the management of human capital since employees are the main carriers and processors of knowledge(Nermien Al-Ali, 2003, p66).

\subsection{The Second Stage: Managing IC as Innovation Resources:}

At this stage the value of IC in the first stage is extracted at this stage when it can be materialized. The best way to describe IC at this stage is as innovation resources. This stage is mostly focused on the management of customer capital since innovation in the knowledge economy is increasingly reliant on network-based innovation(Nermien Al-Ali, 2003, p66).

\subsection{The Third Stage: Managing IC as Intellectual Property:}

At this stage, IC has reached its optimal level of materialized value. The best way to describe intellectual capital at this stage is intellectual property or intellectual assets. This stage is mostly focused on the management of structural capital given that IP is owned by the organization(Nermien Al-Ali, 2003, p67).

The ICM model brings different practices, objectives, programs, and tools together in an understandable framework.

\section{General Determinants of Competitiveness}

- Government intervention;

- Quality of services offered;

- Price of services offered;

- Productivity and performance.

- Competitive advantage of the organization.

\section{Research Model}

According to the literature, intellectual capital management can affect competitiveness with three main areas: knowledge management, innovation management and intellectual property management.

The model of research factors:

\begin{tabular}{|c|c|}
\hline Independent Variable & Dependent Variable \\
\hline Intellectual capital management & \\
\hline $\begin{array}{ll}- & \text { Knowledge management } \\
- & \text { Innovation management } \\
- & \text { Intellectual property management }\end{array}$ & Competitiveness \\
\hline
\end{tabular}




\subsection{Knowledge Management Stage}

Knowledge management in intellectual capital management model presents the stage at which the knowledge resources of an organization are deployed and reconfigured to create value, to form the basis for achieving the organization's goals through activities, processes of create values, innovation to extracting value, or commercialization to getting maximum profits.

- Organizational memory loss and brain drain;

- Tacit/Explicit Knowledge Conversions;

- Strategizing knowledge management from applying a gap analysis, also known as a knowledge audit and adopting the knowledge strategies;

- Operationalizing knowledge management: involves a number of steps aimed at emancipating the knowledge creation process from the rigid organizational structure, ensuring that the right culture is in place, and supporting knowledge creation processes with requisite knowledge resources (knowledge base) and IT tools(Nermien Al-Ali, 2003, p90).;

- Storytelling or anecdote management-an ancient art revived.

\subsection{Innovation Management Stage}

Innovation management is the stage at which value created at the knowledge management (KM) stage is extracted by transforming knowledge into a product or a work process.

- Utilization of networks in innovation management;

- Escalation innovation management to the strategic level of the organization, where innovation strategies play two roles. First, they form part of the competitive strategy of the organization. Second, innovation strategies crystallize the mix of innovation portfolio and the way of circulate innovation management across the whole organization;

- Operationalizing innovation management, by adopting structural changes, spreading a culture for innovation and liberate the innovative spirit;

- Enabling systems, practices, and tools: creating banks to gathered ideas from the human resource of the organization, adopting flexible management style of innovation management to get optimal exploitation of their customer capital, using competitive intelligence, technology management and patent intelligence to enforce the structural capital of the organization.

\subsection{Intellectual Property Management Stage}

- $\quad$ Taking intellectual property management to the strategic level in the organization: Managing IP at the strategic level based on the auditing of the primary form of IP to create an IP portfolio;

- $\quad$ Operationalizing IPM — with all due respect to the legal department: Structural Changes, Cultural Changes;

- Enabling Tools and Practices-IP Valuation.

\section{Research Problem}

Competitiveness is a topic of major interest for many organizations to monitor her success and excellence.

Understanding the competitiveness is an important factor in determining whether it prospers, barely gets by, or fails, and "Several authors stress that competitiveness does not have a definition in economic theory"(e.g. Sharples, 1990; Ahearn et al., 1990).

Competitiveness can be defined as the ability to face competition and to be successful when facing competition. And as how effectively an organization meets the wants and needs of customers relative to others that offer similar goods or services.

Therefore, in order for managers of Algerian insurance organizations to manage their intellectual capital to achieve high standards of excellence in meeting their costumers' wants and needs.

We can find many publications on competitiveness in a lot of sectors but little empirical data have been gathered on the competitiveness of Algerian insurance sector. This research will study the role of intellectual capital management in enhancing the competitiveness of Algerian insurance organizations. 


\section{Research Hypotheses}

This research framework was developed in accordance with the literature review. From the review, it was noticed that intellectual capital management is related to business competitiveness.

The Intellectual Capital management Variables defined in this study is in relation to (Nermin al Ali, 2003) classification of intellectual capital management: Knowledge management, innovation management, and intellectual property management. Their interrelation and their impact on Business competitiveness will be tested.Therefore, the following four principle hypotheses are developed.

H1: There is statistically significant on the existence of "intellectual capital management (ICM)" in Algerian insurance companies, and this hypothesis will split into the sub-hypotheses;

H2: There is statistically significant on the existence of the "Competitiveness" in Algerian insurance companies;

H3: There is statistically significant relationship between "Intellectual Capital Management" and "Competitiveness" in Algerian insurance companies,

H4: there is a statistically significant difference amongst Algerian insurance organizations due to privacy determinants (type, experience and turnover).

\section{Research Objectives}

- To define the exploitation level of intellectual capital management in Algerian insurance organizations.

- To test the relationship between competitiveness of Algerian insurance organizations and knowledge management (Organizational memory, Tacit /Explicit Knowledge Conversions, strategizing and operationalzing knowledge management).

- To test the relationship between competitiveness of Algerian insurance organizations and innovation management (Network-based innovation, Strategizing and operationalzing innovation management, Enabling systems, practices, and tools).

- To test the relationship between competitiveness of Algerian insurance organizations and intellectual property management (Strategizing IPM, Operational zing IPM, Enabling Tools and Practices).

- To give recommendations for the management of Algerian insurance organizations regarding the intellectual capital management and his importance in enhancing their competitiveness.

\section{Literature Review}

Many researches proved that intellectual capital management has been a popular subject for researchers in a wide area of fields including industrial, public and private business(Nihaya El-Telbani, 2012,p128) and insurance sector. The study will compare finding of this research with modern previous studies in the insurance sector to provide some results and recommendation for Algerian Insurance Companies.

\subsection{Mohammad Vafaee Yeganeha, Bahman Yasbolaghi SHarahi (2014)}

The main purpose of this study is to investigate the intellectual capital condition and its components (human capital, customer capital and structural capital) in public and private insurance companies and the effect of the type of ownership of the insurance companies (public and private) on the degree of importance of intellectual capital and its components. The present study is a descriptive survey method in term of data collection. The findings revealed that type of ownership of the insurance companies only has significant effect on human capital variable and has not any significant effect on customer capital and structural capital variables. Also the type of ownership of the insurance companies has significant effect on intellectual capital variable and that the condition of intellectual capital in private insurance companies is more appropriate compared with public insurance companies(Mohammad Vafaee Yeganeha, Bahman Yasbolaghi SHarahi, 2014, p1).

\subsection{Chen, Fu-Chiang, Liu, Z.-John and Kweh and Qian Long (2014)}

In their study, they investigate changes in productivity of general insurance firms in Malaysia for the period from 2008 to 2011. Moreover, their study examines the impact of intellectual capital on changes in productivity through OLS and Tobit regressions. They provide a recommendation that general insurers in Malaysia must invest in intellectual capital, 
including the improvement of their managerial skills, to gain sustainable growth in productivity (Chen, Fu-Chiang et al, 2014, p1).

\subsection{Qian Long Kweh, Wen-Min Lu(2014)}

In this study the researchers investigate the impact of intellectual capital (IC) on operating performance. They find that the overall performance of life insurance companies in China was better than that of life insurance companies in Taiwan. Their results also showed that human capital $(\mathrm{HC})$ and structural capital $(\mathrm{SC})$ had impacts on the operating performance of life insurance companies(Qian Long Kweh, Wen-Min Lu(2014, p1).

\subsection{Wasim-ul-Rehman, Nabila Asghar and Hafeez ur Rehman (2013)}

The main purpose of this study is to measure the intellectual capital performance of insurance sector for the period 20062010 using both Value Added (VA) and Value Added Intellectual Coefficient (VAICTM) model and observe intellectual capital performance's impact on financial returns of both life and non-life insurance sector. Using panel data the study analyzes the empirical relationship of Value Added (VA), VAICTM and its performance components with performance indicators of insurance sector. The results of the study reveal the existence of positive relationship between the two approaches, VA and VAICTM and financial performance indicators. As far as the existence of relationship between the performance components of VAICTM and financial performance indicators is concerned, earning per share (EPS) is positively related to human capital efficiency (HCE). There emerges a negative relationship between capital employed efficiency (CEE) and returns on investment (ROI)( Wasim-ul-Rehman et al, 2013, p1).

\subsection{Atef Odwan, Sahar Suleiman (2012)}

The aim of the study is to identify the intellectual capital and its role in Organizational Innovation, and to verify that there is a moral and an effective relation between the intellectual capital with its three elements (human, structural, customer) and the Organizational Innovation with its three levels (individual, group, and organization). The population of the study was managers from the top, executive and operational management levels from (18) Jordanian Insurance companies. The sample of the study included (80) manger in various administrative levels representing the 18 Jordanian insurance companies, an (80) questionnaire were distributed for the study, (75) were retrieved from the managers, only 50 questionnaire of the 80 was good enough to the study. The study used a set of statistical methods to analyze the data and to test the hypothesis that includes the frequencies, percentages, averages, and the standard deviations, as well as correlation coefficient level of Spearman, Simple correlation coefficient and simple regression analysis. The conclusion of the study is:There is a significant correlation between the intellectual capital and Organizational Innovation(Atef Odwan, Sahar Suleiman, 2012, p1).

\section{Research Methodology}

\subsection{Research Instrument}

The dimensions of this study and the number of the related items for each one are presented in the following table:

Table (1): The research' dimensions

\begin{tabular}{|c|c|c|}
\hline No & Dimensions & No. of Items \\
\hline 1 & Create value by knowledge management (KM) & 20 \\
\hline 2 & Extract value by Innovation management (KM) & 11 \\
\hline 3 & Maximize value by intellectual property management (IPM) & 9 \\
\hline 4 & Competitiveness (C) & 9 \\
\hline \multicolumn{2}{|c|}{ Total } & 49 \\
\hline
\end{tabular}

\subsection{Sample of the study}

A simple random sample is used where 551 managers or directors of the Insurance Algerian organizations were 
surveyed as recommended by (Bontis, 1998 and Bukh et al,1999).

\subsection{Statistical Society}

In this research, limited society is used because we can count and inventory of all the component units of the society studied. A limited society is used where 23 Algerian Insurance Organizations and 16 Algerian Insurance Organizations responded (response rate 70\%). And the managers members responded are:

So the percentage of responded members in all the Algerian Insurance Organizations is (26\%).

\begin{tabular}{|c|c|c|c|}
\hline Category & Number of surveyed & Number of responses & Percentage \\
\hline General manager & 16 & 9 & $56 \%$ \\
\hline Regional manager & 51 & 19 & $37 \%$ \\
\hline Agency manager & 500 & 181 & $36 \%$ \\
\hline Total & $\mathbf{5 5 1}$ & $\mathbf{2 0 9}$ & $\mathbf{3 8 \%}$ \\
\hline
\end{tabular}

\subsection{Statistical Treatment}

This research will use ordinal scales. Where the number assigned to the important $(1,2,3,4,5)$ do not indicate that the interval between scales are equal, nor do they indicate absolute quantities. They are merely numerical labels(Nihaya ElTelbani, 2012,p129). Based on Likert scale we have the following table:

\begin{tabular}{|c|c|c|c|c|c|}
\hline Item & Always & often & Occasionally & Rarely & Never \\
\hline scale & 5 & 4 & 3 & 2 & 1 \\
\hline
\end{tabular}

Table (3) shows the results for Kolmogorov-Smirnov and Shapiro Wilks test of normality. From table (3), the ( $p$ value $=0.000$ ) for each field is smaller than 0.05 level of significance, then the distribution for each field is not normally distributed.

Table (3): Kolmogorov-Smirnov and Shapiro Wilks test of normality

\begin{tabular}{|c|c|c|c|c|c|c|}
\hline & \multicolumn{9}{|c|}{ Kolmogorov-Smirnova } & \multicolumn{3}{c|}{ Shapiro-Wilk } \\
\cline { 2 - 7 } & Statistique & ddl & Signification & Statistique & ddl & Signification \\
\hline KMS &, 330 & 209 &, 000 &, 801 & 209 &, 000 \\
INS &, 250 & 209 &, 000 &, 819 & 209 &, 000 \\
IPMS &, 185 & 209 &, 000 &, 912 & 209 &, 000 \\
COMP &, 237 & 209 &, 000 &, 812 & 209 &, 000 \\
\hline
\end{tabular}

a. Correction de signification de Lilliefors

Consequently, this study will use non-parametric tests to perform the statistical data analysis. The data will therefore be analyzed using (SPSS). The research would utilize the following statistical tests:

1- Spearman Rank correlation for Validity.

2- Cronbach's Alpha for Reliability Statistics.

3- Kruskal-Wallis test.

\section{Questionnaire}

10.1 Questionnaires validity: Statistical validity is used to evaluate instrument validity, by using the structure validity.

\subsubsection{Structure Validity of the Questionnaire}

Structure validity is for testing the validity of each field and the validity of the whole questionnaire. It measures the correlation coefficient between one field and all the fields of the questionnaire that have the same level of liker scale. 
Table (8): Correlation coefficient of each field and the whole of questionnaire

\begin{tabular}{|c|l|c|c|}
\hline $\mathbf{N}^{\circ}$ & Paragraph & Spearman Correlation Coefficient & P-value (sig) \\
\hline 1 & Creating value by knowledge management stage & 0.879 & $0.000^{\star \star}$ \\
\hline 2 & Extracting value by innovation management stage & 0.965 & $0.000^{\star *}$ \\
\hline 3 & Maximizing value by intellectual property management stage & 0.921 & $0.000^{\star \star}$ \\
\hline 4 & Competitiveness & 0.749 & $0.000^{\star \star}$ \\
\hline
\end{tabular}

Table (8) presents the correlation coefficient between each filed and the whole questionnaire. Noticeable that the $\mathrm{p}$ values (sig.) are less than 0.01 , so the coefficient of correlation in all the fields is significant at $\alpha=0.01$, so that the fields are valid to measure what it was set for and to achieve the purpose of the study.

\subsection{Questionnaires reliability}

The studies used the reliability of an instrument to measure the degree of consistency which measures the attribute. Reliability can be replaced by the stability, consistency, or dependability of a measuring tool(Nihaya El-Telbani, 2012,p130).

\subsubsection{Cronbach's Coefficient Alpha}

In this study we use this coefficient to measure the reliability of the questionnaire between each field and the mean of the whole fields of the questionnaire. When it supposed that the normal range of Cronbach's coefficient alpha value is between 0.0 and (+1.0), and the higher values reflects a higher degree of internal consistency(Zikmund, W. G. (2003). Table (9) shows the values of Cronbach's alpha for each filed and the entire questionnaire. The results of fields show that values of Cronbach's alpha were in the range from 0.677 and 0.944 . This range is considered high; the result ensures the reliability of each field of the questionnaire. Cronbach's alpha equals 0.944 for the entire questionnaire which indicates an excellent reliability of the entire questionnaire.

Table (9): Cronbach's Alpha for each filed and the entire questionnaire

\begin{tabular}{|c|l|c|}
\hline $\mathbf{N}^{\circ}$ & Field & Cronbach's alpha \\
\hline 1 & Creating value by knowledge management stage & 0.881 \\
\hline 2 & Extracting value by innovation management stage & 0.772 \\
\hline 3 & Maximizing value by intellectual property management stage & 0.905 \\
\hline 4 & Competitiveness & 0.677 \\
\hline & All paragraphs of the questionnaire & 0.944 \\
\hline
\end{tabular}

\section{The Study Sample' Profile}

The study sample' profile is presented in table (10):

Table (10): The of study sample' profile

\begin{tabular}{|c|c|c|}
\hline \multicolumn{2}{|c|}{ Type } & Percent \\
\hline \multirow{4}{*}{ Yeablic } & 64.11 \\
\cline { 2 - 3 } & Private & 15.31 \\
\cline { 2 - 3 } & International & 20.58 \\
\cline { 2 - 3 } & Total & $100 \%$ \\
\hline \multirow{4}{*}{ Years of experience } & Less than 10 years & 4.79 \\
\cline { 2 - 3 } & 10-less than 20 & 40.67 \\
\cline { 2 - 3 } & 20 and above & 54.54 \\
\cline { 2 - 3 } & Total & $100 \%$ \\
\hline \multirow{4}{*}{ The turnover } & Less than 5Billion DA & 41.67 \\
\cline { 2 - 3 } & 5-less than 10 & 12.94 \\
\cline { 2 - 3 } & 10-less than15 & 10.54 \\
\cline { 2 - 3 } & 15-less than20 & 30.79 \\
\cline { 2 - 3 } & 20 and above & $100 \%$ \\
\cline { 2 - 3 } & Total & 06 \\
\cline { 2 - 3 } & &
\end{tabular}




\section{Empirical Analysis and Hypothesis Testing}

$\mathrm{H1}$ : There is statistically significant on the existence of intellectual capital management (ICM) in Algerian insurance companies, this hypothesis can split into the following sub-hypotheses:

$\mathrm{H} 1$ (a): There is a statistically significant on the existence of "Creating value from Knowledge Management Stage" in Algerian insurance companies:

Table (11): Means and standard deviation for "«Creating value from knowledge management stage".

\begin{tabular}{|c|c|c|c|c|c|}
\hline & Creating value from knowledge management stage & Mean & S.D & Test value & p-value \\
\hline 1 & You have a strategic shift of vision where recognize yourself as a knowledge organization. & 3.97 & 1.004 & 3.727 & 0.000 \\
\hline 2 & You are adapting knowledge strategy. & 4.11 & 0.994 & 3.771 & 0.000 \\
\hline 3 & You have policies or programs intended to improve worker retention. & 4.80 & 0.514 & 7.302 & 0.000 \\
\hline 4 & You use partnership or strategic alliance to acquire knowledge & 4.35 & 1.073 & 5.473 & 0.000 \\
\hline 5 & You change the organizational culture to be knowledge organization. & 3.71 & 1.105 & 3.020 & 0.000 \\
\hline 6 & You change the organizational structure to be knowledge organization. & 3.75 & 0.939 & 3.925 & 0.000 \\
\hline 7 & You try to eliminate the level of departmental and divisional isolationism. & 4.07 & 1.284 & 4.645 & 0.000 \\
\hline 8 & You encourage the collaboration among people in the organization. & 4.66 & 0.689 & 6.846 & 0.000 \\
\hline 9 & Your organization knows what it knows. & 3.87 & 0.457 & 6.277 & 0.000 \\
\hline 10 & You give a Monetary incentive to your employees. & 2.92 & 1.512 & 2.504 & 0.000 \\
\hline 11 & you give a Nonmonetary incentive to your employees & 3.77 & 0.953 & 3.832 & 0.000 \\
\hline 12 & Usage IT tools and systems to performing the knowledge management stage. & 4.39 & 0.819 & 5.429 & 0.000 \\
\hline 13 & Usage of IT tools for the interaction between individual and organizational knowledge & 4.35 & 0.807 & 5.056 & 0.000 \\
\hline 14 & Usage of IT tools and systems for the Tacit/ Explicit knowledge conversions. & 3.54 & 1.109 & 2.669 & 0.000 \\
\hline 15 & Regularly up dating databases of good work practices, lessons learned or listing of experts. & 4.26 & 1.209 & 5.161 & 0.000 \\
\hline 16 & Provide formal training related to knowledge management practices. & 2.10 & 1.630 & 6.210 & 0.000 \\
\hline 17 & Provide informal training related to knowledge management. & 3.22 & 1.252 & 3.868 & 0.000 \\
\hline 18 & Encourage experienced worker to transfer their knowledge to new and less experienced workers. & 2.17 & 1.211 & 3.388 & 0.000 \\
\hline 19 & Encourage workers to continue their education for successfully completed work-related courses. & 4.70 & 0.945 & 7.558 & 0.000 \\
\hline 20 & Facilitating virtual teams. & 3.72 & 1.494 & 5.199 & 0.000 \\
\hline & All paragraphs of the field & 3.87 & 0.767 & 4.427 & 0.000 \\
\hline
\end{tabular}

The table (11) presented above presents the following results:

The mean, Standard deviation equals, Test-value of all paragraphs of the field "Creating value from knowledge management stage" are respectively equal to (3.87 (77.4\%), (0.767), 4.427) and the value of significance equal to 0.000 which is smaller than the level of significance $(a=0.01)$, so the mean is greater than the hypothesized value 3 . We can conclude that the respondents are agreeing on the content of this dimension "Creating value from knowledge management stage" in Algerian insurance companies.

$\mathrm{H} 1(\mathrm{~b})$ : There is a statistically significant on the existence of «Extracting value from innovation management stage" in Algerian insurance companies:

Table (12): Means and standard deviation for «Extracting value from innovation management stage"

\begin{tabular}{|c|c|c|c|c|c|}
\hline & «Extracting value from innovation management stage" & Mean & S.D & $\begin{array}{c}\text { Test } \\
\text { value }\end{array}$ & $\begin{array}{c}\mathrm{p}- \\
\text { value }\end{array}$ \\
\hline 1 & You are adapting an innovation strategy. & 3.41 & 1.057 & 3.801 & 0.000 \\
\hline 2 & You have values system or culture intended to promote (IM). & 3.12 & 1.256 & 3.739 & 0.000 \\
\hline 3 & You change the organizational culture and structure to be more flexible. & 3.84 & 1.019 & 3.484 & 0.000 \\
\hline 4 & Facilitate the forming of cross-functional innovation teams. & 3.87 & 1.266 & 4.150 & 0.000 \\
\hline 5 & The use of carefully designed reward to encourage innovation & 1.86 & 1.273 & 5.042 & 0.000 \\
\hline 6 & You Have a bank idea & 4.24 & 1.178 & 4.466 & 0.000 \\
\hline 7 & $\begin{array}{l}\text { You seek and gather idea and knowledge, from customers, suppliers, employees, other industries and } \\
\text { competitors }\end{array}$ & 2.78 & 1.581 & 2.753 & 0.000 \\
\hline 8 & $\begin{array}{l}\text { Capturing and using knowledge obtained from public research institutions including universities, technical } \\
\text { colleges }\end{array}$ & 4.37 & 1.044 & 5.259 & 0.000 \\
\hline 9 & Encouragement the diversity of viewpoint, talent and expertise. & 3.50 & 1.286 & 3.778 & 0.000 \\
\hline 10 & The involvement of customers at innovation management to help the new product development team. & 2.95 & 1.444 & 3.165 & 0.000 \\
\hline & $\begin{array}{l}\text { The incorporating of a competitive intelligence system in the organization's work systems (i.e., be cultivated } \\
\text { as part of the structural capital). }\end{array}$ & 2.36 & 1.532 & 4.621 & 0.000 \\
\hline & All paragraphs of the field & 3.27 & 0.744 & 4.085 & 0.000 \\
\hline
\end{tabular}


The table (12) presented above presents the following results:

The mean, Standard deviation equals, Test-value of all paragraphs of the field «Extracting value from innovation management stage" are respectively equal to $(3.2765 .4 \%, 0.744,4.085)$, and the value of significance equal to 0.000 which is smaller than the level of significance $(\alpha=0.01)$, so the mean is greater than the hypothesized value 3 . We can conclude that the respondents are agreeing on the content of this dimension «Extracting value from innovation management stage" in Algerian insurance companies.

$\mathrm{H} 1$ (c): There is a statistically significant on the existence of "Maximizing value from intellectual property management stage" in Algerian insurance companies;

Table(13): Means and standard deviation for «Maximizing value from intellectual property management stage".

\begin{tabular}{|c|c|c|c|c|c|}
\hline & «Maximizing value from IPM stage" & Mean & S.D & $\begin{array}{c}\text { Test } \\
\text { value }\end{array}$ & $\begin{array}{c}\mathrm{p}- \\
\text { value }\end{array}$ \\
\hline 1 & Your organization put the intellectual property strategies as a part of the competitive strategies. & 3.45 & 1.263 & 2.978 & 0.000 \\
\hline 2 & IN your organization, at strategic level, the intellectual property they have across the whole organization is clear. & 3.91 & 1.157 & 3.988 & .000 \\
\hline 3 & $\begin{array}{l}\text { Your organization incorporating the knowledge of patents, trademarks (brands), copyrights, and trade secrets to } \\
\text { create synergy between the management of the various forms of intellectual property. }\end{array}$ & 2.66 & 1.183 & 2.667 & .000 \\
\hline 4 & Management of intellectual property as a business asset throughout the whole organization. & 3.78 & 1.060 & 2.676 & .000 \\
\hline 5 & $\begin{array}{l}\text { IPM has to shift from a defensive and legal-oriented to an integrative approach wherein it is engrained in the } \\
\text { management of business as a whole. }\end{array}$ & 3.06 & 1.389 & 2.907 & .000 \\
\hline 6 & You change culture to create an intellectual property aware culture. & 3.99 & 1.076 & 3.310 & .000 \\
\hline 7 & $\begin{array}{l}\text { The responsibility of capitalizing on IP is handed down to the various business units, to operationalize the IP } \\
\text { strategies forged by top management. }\end{array}$ & 3.11 & 1.210 & 3.038 & .000 \\
\hline 8 & $\begin{array}{l}\text { Your organization provided with IT tools that aid decision making in the intellectual property management } \\
\text { processes. }\end{array}$ & 3.22 & 1.461 & 2.400 & .000 \\
\hline 9 & $\begin{array}{l}\text { Your organization provided with methods that aid decision making in the intellectual property management } \\
\text { processes. }\end{array}$ & 2.83 & 1.476 & 3.677 & .000 \\
\hline & All paragraphs of the field & 3.27 & 1.064 & 3.572 & .000 \\
\hline
\end{tabular}

The table (13) presented above presents the following results:

The mean, Standard deviation equals, Test-value of all paragraphs of the field «Maximizing value from intellectual property management stage" are respectively equal to $(3.27(65.4 \%), 1.064,3.572)$, and the value of significance equal to 0.000 which is smaller than the level of significance $(a=0.01)$, so the mean is greater than the hypothesized value 3 . We can conclude that the respondents are agreeing on the content of this dimension «Maximizing value from intellectual property management stage" in Algerian insurance companies.

$\mathrm{H} 2$ : There is statistically significant on the existence of the "Competitiveness" in Algerian insurance companies;

Table(14): Means and standard deviation for « Competitiveness".

\begin{tabular}{|c|c|c|c|c|c|}
\hline & Competitiveness & Mean & S.D & T-value & p-value \\
\hline 1 & The government intervened in your business. & 3.27 & 0.639 & 4.182 & .000 \\
\hline 2 & Adaptation of a strategy to deal with the new competition. & 4.49 & 0.659 & 5.249 & .000 \\
\hline 3 & You move faster than your competitors in the market. & 3.99 & 0.874 & 3.727 & .000 \\
\hline 4 & You have an increasingly rise of market share. & 4.26 & 0.614 & 4.506 & .000 \\
\hline 5 & Implementation of quality improvement in your business, to increase productivity and performance. & 4.00 & 0.616 & 4.506 & .000 \\
\hline 6 & Improvements in design of new product to increase your share market and strong your competitive position. & 4.08 & 1.067 & 3.914 & .000 \\
\hline 7 & Improvement of customer satisfaction through customization. & 3.02 & 1.297 & 4.763 & .000 \\
\hline 8 & Investments in image, brand and communication. & 3.65 & 1.248 & 4.148 & .000 \\
\hline 9 & Investments in patents to protect your competitive advantage. & 2.39 & 1.232 & 2.601 & .000 \\
\hline & All paragraphs of the field & 4.00 & 0.772 & 2.940 & .000 \\
\hline
\end{tabular}

The table (14) presented above presents the following results:

The mean, Standard deviation equals, Test-value of all paragraphs of the field «Competitiveness" are respectively equal to $(4.00(80 \%), 0.772,2.940)$, and the value of significance equal to 0.000 which is smaller than the level of significance $(\alpha=0.01)$, so the mean is greater than the hypothesized value 3 . We can conclude that the respondents are agreeing on the content of this dimension « Competitiveness in Algerian insurance companies.

H3- There is statistically significant relationship between "Intellectual Capital Management" and "Competitiveness" 
in Algerian insurance companies, this hypothesis can be divided into the following sub-hypotheses:

Table(15): Spearman coefficient correlation of each field and competitiveness

\begin{tabular}{|c|c|c|c|c|c|c|c|}
\hline & & & KMS & IMS & IPMS & competitinevess & $\mathrm{ICM}$ \\
\hline \multirow{15}{*}{ Rho de Spearman } & \multirow{3}{*}{ KMS } & Coefficient de corrélation & 1,000 &, $561^{* *}$ &, $680^{* *}$ &, $508^{* *}$ & $806^{* *}$ \\
\hline & & Sig. (bilatérale) & . &, 000 & ,000 & ,000 &, 000 \\
\hline & & $\mathrm{N}$ & 209 & 209 & 209 & 209 & 209 \\
\hline & \multirow{3}{*}{ IMS } & Coefficient de corrélation &, $561^{* *}$ & 1,000 &, $349^{* *}$ &, $316^{* *}$ & $622^{* *}$ \\
\hline & & Sig. (bilatérale) & ,000 & . &, 000 & ,000 &, 000 \\
\hline & & $\mathrm{N}$ & 209 & 209 & 209 & 209 & 209 \\
\hline & \multirow{3}{*}{ IPMS } & Coefficient de corrélation &, $680^{* *}$ &, $349^{* *}$ & 1,000 &, $298^{* *}$ & $672^{* *}$ \\
\hline & & Sig. (bilatérale) &, 000 &, 000 & . & ,000 &, 000 \\
\hline & & $\mathrm{N}$ & 209 & 209 & 209 & 209 & 209 \\
\hline & \multirow{3}{*}{ competitiveness } & Coefficient de corrélation &, $508^{* *}$ &, $316^{* *}$ & $298^{* *}$ & 1,000 & $827^{* *}$ \\
\hline & & Sig. (bilatérale) &, 000 &, 000 &, 000 & . &, 000 \\
\hline & & $\mathrm{N}$ & 209 & 209 & 209 & 209 & 209 \\
\hline & \multirow{3}{*}{ ICM } & Coefficient de corrélation &, $806^{* *}$ &, $622^{* *}$ & $672^{* \star}$ &, $827^{\star *}$ & 1,000 \\
\hline & & Sig. (bilatérale) & ,000 & ,000 &, 000 &, 000 & . \\
\hline & & $\mathrm{N}$ & 209 & 209 & 209 & 209 & 209 \\
\hline
\end{tabular}

**. La corrélation est significative au niveau 0,01 (bilatéral).

H3(a): tested the association connecting knowledge management stage and innovation management stage. The end results show a positive and significant relationship, +0.561 (at $p<0.001)$ for the Algerians insurances organizations sample (see Table 14).

Furthermore, $H 3(b)$ tested the association between knowledge management stage and intellectual property management stage. Finally, the conclusions also illustrate a positive and significant coefficient +0.680 (at $p<0.01$ ).

Moving on, a positive significant coefficient for the sample $(+0.349)$ (at $p<0.001$ ) confirmed the $H 3(c)$ (intellectual property management is positively associated with innovation management in Algerian Insurance organizations).

$H 3(d)$ tested the relationship between knowledge management stage and competitiveness, and according to the result in the sample there is a positive coefficient $(+0.508)$, (at $p<0.001)$.

$H 3(e) t e s t e d$ the relationship between innovation management stage and competitiveness, and according to the result in the sample there is a positive coefficient $(+0.316)$, (at $p<0.001), H 3(f)$ tested the association between intellectual property management stage and the competitiveness. The results show a positive coefficient $(+0.298$ at $p<0.001)$.

Finely, H3: tested the association between intellectual capital management and the competitiveness. The results show a positive coefficient $(+0.827$ at $p<0.001)$, (see Table14).

$\mathrm{H} 4$ : there is a statistically significant difference amongst Algerian insurance organizations due to privacy determinants (type, experience and turnover), this hypothesis can be divided into the following sub-hypotheses:

H4(a): there is a statistically significant difference amongst Algerian insurance organizations due to type (public, private and international);

Table(16): Kruskal-Wallis test of the fields and their P-values for type (Public, private and international)

\begin{tabular}{|c|c|c|c|c|c|}
\hline & K-M-S & I-M-S & IP-M-S & competitiveness & ICM \\
\hline Khi-deux & 115.376 & 61.988 & 40.819 & 126.564 & 123.322 \\
\hline $\mathrm{N}$ & 2 & 2 & 2 & 2 & 2 \\
\hline Significant & 0.000 & 0.000 & 0.000 & 0.000 & 0.000 \\
\hline
\end{tabular}

**The mean difference is significant a 0.01 level

Table (15) shows that (P-value $=0.000)$ of each field is smaller than the level of significance $(0.01)$. There is a statistically significant relationship difference amongst Algerian insurance companies toward "The role of intellectual capital management in enhancing organization' competitiveness" due to type of company (public, private or international).

$\mathrm{H4}(\mathrm{b})$ : there is a statistically significant difference amongst Algerian insurance organizations due to experience; 
Table(17): Kruskal-Wallis test of the fields and their P-values for experience

\begin{tabular}{|c|c|c|c|c|c|}
\hline & K-M-S & I-M-S & IP-M-S & competitiveness & ICM \\
\hline Khi-deux & 98.419 & 25.757 & 24.142 & 17.986 & 29.259 \\
\hline $\mathrm{N}$ & 2 & 2 & 2 & 2 & 2 \\
\hline Significant & 0.000 & 0.000 & 0.000 & 0.000 & 0.000 \\
\hline
\end{tabular}

**The mean difference is significant a 0.01 level

Table (16) shows that (P-value $=0.000$ ) of each field is smaller than the level of significance $(0.01)$. There is a statistically significant relationship difference amongst Algerian insurance companies toward "The role of intellectual capital management in enhancing organization' competitiveness" due to experience of Algerian insurance organizations. H4(c): there is a statistically significant difference amongst Algerian insurance organizations due to turnover;

Table(18): Kruskal-Wallis test of the fields and their P-values for Turnover

\begin{tabular}{|l|l|l|l|l|l|}
\hline & K-M-S & I-M-S & IP-M-S & competitiveness & ICM \\
\hline Khi-deux & 111.655 & 140.308 & 53.461 & 10.242 & 30.240 \\
\hline N & 4 & 4 & 4 & 4 & 4 \\
\hline Significant & 0.000 & 0.000 & 0.000 & 0.000 & 0.000 \\
\hline
\end{tabular}

**The mean difference is significant a 0.01 level

Table (17) shows that (P-value $=0.000$ ) of each field is smaller than the level of significance $(0.01)$. There is a statistically significant relationship difference amongst Algerian insurance companies toward "The role of intellectual capital management in enhancing organization' competitiveness" due to turnover of Algerian insurance organizations.

\section{Conclusion}

The results from this study are as expected and significantly supportive to the hypotheses developed.

- The first hypothesis proved that the Algerian Insurance organizations manage their intellectual capital, by managing knowledge management to create value (mean=3.87), manage innovation to extract value (mean=3.27) and manage the intellectual property to maximize value in the market (mean=3.27);

- The second hypothesis proved that the Algerian Insurance organizations have a competitiveness in their market (mean= 4);

- The third hypothesis proved that the relationship between ICM and competitiveness is positive. This relationship is by value close to 0.827 in this sample of Algerian insurance organizations.

- The fourth hypothesis proved that the there is a statistical significant difference amongst Algerian insurance organizations due to privacy determinants like their type, years of experience in the market of insurance and their turnover.

\section{Recommendations}

It is essential before embarking on implementing any ICM stage or program to ensure that the organization has the appropriate business model, vision, and culture in place-in short, to ensure that it has its act together.

There is a need in Algerian Insurance Organizations to recognize knowledge management as the first stage of a total model of intellectual capital management where the organization deploys its resources to enhance their competitiveness, especially in the economy of knowledge;

There is a need in Algerian Insurance Organizations to adopt flexible innovation management, and utilize networks based innovation to spread the culture and possess of innovation across the whole organization;

There is a need in Algerian Insurance Organizations to creating an innovation portfolio of projects to translate competitive strategies and to manage risk across the whole organization.

There is a need in Algerian Insurance Organizations to effecting the necessary structural changes (culture, structure, information technology tools) to arrange skills throughout the organization in competence centers, and enable the formation of the right team for the purposes of the innovation project.

There is a need in Algerian Insurance Organizations to adopt and mainstream an organizational culture that 
promotes innovation by allowing employees time to innovate for improving job performance.

There is a need in Algerian Insurance Organizations to know and assess the intellectual property wealth of the organization and assess its current and potential uses, particularly in relation to the primary form of intellectual property.

There is a need in Algerian Insurance Organizations to build a strong IP portfolio by combining weak with strong $I P$, reinforcing strong IP through acquiring additional supporting same or different forms of $I P$, and abandoning lowperforming IPS.

There is a need in Algerian Insurance Organizations to adopt IP strategies that enable the use of IP as a competitive weapon (lawfully) to hamper competition's efforts in securing a strong competitive position for short- and medium-term purposes.

There is a need in Algerian Insurance Organizations to adopt IP strategies to sustain and create new competitive advantage in the long term.

There is a need in Algerian Insurance Organizations to adopt intellectual property strategies for commercialize it as a business asset to expand geographically and be able to take more market shares and destroy their competitors;

There is a need in Algerian Insurance Organizations to take intellectual property management to the operational level by effecting the necessary changes to the structure of the organization, and allocating responsibility to intellectual property teams and units;

There is a need in Algerian Insurance Organizations to instill in the culture of the organization awareness of the proper use of IP by establishing sound management practices, both to preserve the value of IP and to guard against infringing the IP of others.

There is a need in Algerian Insurance Organizations to provide tools and systems to help the employers at the operational levels to managing intellectual property. In particular, using tools for the valuation of intellectual property.

\section{References}

Atef Odwan, Sahar Suleiman, "The Intellectual Capital and its Role in Organizational Innovation (Field Study in Jordanian Insurance Companies)" Dirasat: Administrative Sciences, Vol39, No 2 (2012), p(1).

Buckley, P.J. and Carter, M.J.,(2000) "Knowledge management in global technology markets applying theory to practice", Long Range Planning, 33(1), , pp. 55-71.

Chen, Fu-Chiang, Liu, Z.-John and Kweh and Qian Long, « Intellectual capital and productivity of Malaysian general insurers", Elsevier in its journal Economic Modelling, Volume (Year): 36 (2014), Pages: 413-420.

Dimitrios Maditinos, Željko Šević, Charalampos Tsairidis, « Intellectual Capital and Business Performance: An Empirical study for the Greek Listed Companies", 7th International Conference on Accounting and Finance in Transition (ICAFT) 23-25 July 2009, Greenwich, London, pp.14-17.

Goran Roos \&others, «Management Intellectual Capital in Practice », Elsevier, New York, 2005.

Guthrie, J. and Petty, R.,(1999) "Knowledge management", Company Secretary (Hong Kong), 9(1), pp. 38-41.

Indra Abeysekera, « Intellectual Capital Accounting : Practices in a developing country », 1st publication, Routledge, USA, 2008, p8.

Johanson, U., Martenson, M. and Skoog, M., (1999), "Measuring and managing intangibles, Eleven Swedish qualitative exploratory case studies", Working paper, Presented at EIASM's workshop, Accounting for Intangibles and the Virtual Organisation, Brussels, February.

Lev, B., (2001)," Intangibles: management, measurement, and reporting", Brookings Institution Press, Washington, p17.

Lindsay Moore and Lesley Craig, Esq, "Intellectual Capital in Enterprise Success: Strategy Revisited", Wiley, Canada, 2008, p22.

Mohammad Vafaee Yeganeha, Bahman Yasbolaghi SHarahi, "A Survey of the Relationship between Intellectual Capital and Performance of the Private Insurance Companies of Iran", Procedia-Social and Behavioral Sciences, Volume 114, 21 February 2014, Pages 699-705.

Nermien Al-Ali, "Comprehensive Intellectual Capital Management: Step-by-Step", Wiley, Canada, 2003 , p63.

Nick Bontis, « Intellectual capital: an exploratory study that develops measures and models", MCB University Press [ISSN 0025-1747], National Centre for Management Research and Development, Richard Ivey School of Business, University of Western Ontario, London, 1998, pp. 63-76.

Nihaya El-Telbani, (2012), "The Relationship between Selected Organizational and Personal Variables with Job Satisfaction- An Empirical Study on the Academic Staff of Al Azhar University- Gaza", Zarqa Journal for Research and Studies in Humanities, Jordan, Zarqa University, p130.

Pulic, A. (2005), "Value Creation Efficiency at National and Regional Levels: Case Study - Croatia and the European Union", Bounfour, A. and L. Edvinsson, (eds), "Intellectual Capital for Community - Nations, Regions, and Cities", Elsevier Butterworth-Heinemann.

Schiuma, G., A. Lerro, and D. Carlucci (2005), "An Interfirm perspective on intellectual capital", in Marr B. (eds), perspectives in intellectual capital, Elsevier Butterworth - Heinemann, pp.155-169.

Sveiby, K.E., 2001, "A knowledge-based theory of the firm to guide in strategy formulation," Journal of Intellectual Capital, 2(4), pp. 344358.

Thorne, K. andand Smith, M., 2000, "Competitive advantage in world class organizations", Management Accounting (UK), 78(3), March, 
pp. 22-26.

Tseng, C. Y. and Y. J. J. Goo (2005), 'Intellectual capital and corporate value in an emerging economy: empirical study of Taiwanese manufacturers', R\&D Management, 35(2), pp. 187-201.

Volberda, H.W., Baden-Fuller, C. and van den Bosch, A.J., 2001, "Mastering strategic renewal, mobilising renewal journeys in multi-unit firms", Long Range Planning, 34, pp. 159-178.

Wasim-ul-Rehman, Nabila Asghar and Hafeez ur Rehman, "Intellectual Capital Efficiency and Financial Performance of Insurance Sector in Pakistan: a Panel Data Analysis », Middle-East Journal of Scientific Research 17 (9): 2013, PP. 1251-1259,

Wen-Min Lu, Wei-Kang Wang, Qian Long Kweh, « Intellectual capital and performance in the Chinese life insurance industry », Omega, volume (42), 31 January2014, Pages 65-74.

Zikmund, W. G. (2003), "Business research methods", 7th edition, Ohio: Thomson South-Western. 